\title{
Reflections on Race: The Limits of Formal Equality
}

\section{RUTH COLKER*}

In previous work, I have argued that the formal equality model has not been well equipped to help attain substantive equality for individuals with disabilities, because it does not correctly target who is deserving of assistance and it has not been effective in developing appropriate remedies. ${ }^{1}$ I have suggested that Congress presumed under the Individuals with Disabilities Education Act that an integrated educational environment is better than a more segregated educational environment in the K-12 context, even though the available empirical data do not support that presumption. ${ }^{2}$ I argued that the integration presumption was reflexively borrowed from the racial context without consideration of whether it was effective in the disability context. ${ }^{3}$ I have also applied an anti-subordination perspective to the area of voting to argue that we could do a better job of improving the availability of voting to individuals with disabilities if we moved beyond the integration paradigm to consider how to make in-home voting more accessible to individuals with disabilities. ${ }^{4}$ Throughout that work, I have been agnostic about the remedy of integration and have insisted that integration be chosen as a remedy only when it can be shown to be likely to produce substantive equality relying, in part, on empirical data. ${ }^{5}$

Because my anti-subordination framework, which I have recently applied to the disability context, was initially developed in the race context, ${ }^{6} \mathrm{I}$ have

* Heck-Faust Memorial Chair in Constitutional Law, Michael E. Moritz College of Law, The Ohio State University. I thank Barbara Schwabauer for her assistance with this article. I also thank my colleague Marc Spindelman for reviewing an earlier draft of this article. Finally, I thank the Moritz College of Law for providing me with the research funds to support the work underlying this article.

1 See generally Ruth COLKER, WhEN is SEPARATE UNEQual?: A Disability PERSPECTIVE (forthcoming 2009).

2 See Ruth Colker, The Disability Integration Presumption: Thirty Years Later, 154 U. PA. L. REV. 789, 795-796 (2006).

3 Id. at 790 .

${ }^{4}$ See Daniel P. Tokaji \& Ruth Colker, Absentee Voting by People with Disabilities: Promoting Access and Integrity, 38 MCGEORGE L. REV. 1015, 1017 (2007).

5 See generally Colker, supra note 1.

${ }^{6}$ Ruth Colker, Anti-Subordination Above All: Sex, Race, and Equal Protection, 61 N.Y.U. L. REV. 1003, 1007-08 (1986) ("Under the anti-subordination perspective, it is inappropriate for certain groups in society to have subordinated status because of their lack of power in society as a whole .... From an anti-subordination perspective, both facially differentiating and facially neutral policies are invidious only if they perpetuate racial or sexual hierarchy."). 
decided to return to the race context to see what further insights might arise from that perspective. My anti-subordination perspective can provide two useful insights into the thorny question of the use of race to attain integration in the K-12 public education context. First, this perspective can help us understand why race-conscious tools must continue to be necessary to attain substantive equality. An equality perspective that is not constrained by principles of formal equality will select race-conscious tools in the education area when those tools are likely to improve the educational performance of historically subordinated groups such as African-American children. Second, the remedies that are selected under an anti-subordination perspective will be driven by the empirical data rather than unwarranted presumptions. These data can help us identify that certain types of integrated educational environments are likely to attain positive outcomes for African-American children. The law should support school districts choosing the tools needed to attain those educational environments even if race-conscious means need to be part of that tool chest. In fact, this Article will argue that a failure to use race-conscious tools is likely to lead to unacceptable educational results for many African-American children. The Supreme Court's formal equality model has caused it to leap to various conclusions about appropriate educational programs without examining any empirical literature in depth.

This Article will examine the litigation involving Seattle, Washington, and Jefferson County, Kentucky, to make those arguments. These school districts were the target of extensive litigation, as resolved by the Supreme Court in Parents Involved in Community Schools v. Seattle School District No. $1 .^{7}$ In both cases, the school districts used race-conscious measures to help attain racial integration in their public schools, and, in both cases, the Supreme Court used a formal equality model to resolve the dispute. ${ }^{8}$ Chief Justice Roberts authored the opinion for the Court striking down those plans, in which he made the classic formal equality statement, "The way to stop discrimination on the basis of race is to stop discriminating on the basis of race."9 That approach, I will argue, is simplistic and simply wrong. It reflects a formal equality rather than anti-subordination perspective.

In Part I of this Article, I will discuss the evolution of the specific plans adopted by both school districts so the reader can see the modest nature of the use of race in both cities. Further, I will show that this modest use of race was not a result of data or literature suggesting that such limited uses of race

7127 S. Ct. 2738 (2007) [hereinafter Parents Involved].

8 Id. at $2746,2768$.

${ }^{9} \mathrm{Id}$. at 2768 . This statement was also contained in the Ninth Circuit's dissenting opinion. Parents Involved in Cmty. Schs. v. Seattle Sch. Dist. No. 1, 426 F.3d 1162, 1222 (9th Cir. 2005) (en banc) (Bea, J., dissenting) [hereinafter Parents Involved 9th Circ. IV] ("The way to end racial discrimination is to stop discriminating by race."). 
are most likely to attain the best possible educational gains for minority children. In fact, as I will argue in Part II, the empirical literature suggests that more educational gains would have been likely to have been made through increased use of racial factors in school assignments. The modest use of race was in response to community pressure (by white parents) not to use race at all in school assignment and in response to an awareness of the restrictions imposed by constitutional law. Formal equality has become a political and litigation tool for some white parents to derail an attempt by school districts to create an educational program that is likely to be more successful for minority children.

From an anti-subordination perspective, the courts have the racial equality model exactly backward. The empirical literature, which I will discuss in Part II, suggests that the only way to end race discrimination is to take race into account in school assignments from kindergarten onward. If the school plans were to be struck down in Seattle or Jefferson County, they should have been struck down for not using race enough. School districts, and courts, are caught in the limitations of the formal equality model and therefore try to create school assignment plans that use race as little as possible to achieve token integration. Such token integration is not likely to attain substantive equality for minority children and, ironically, is likely to be struck down by the courts as being too race-conscious. In this Article, I will argue that we should abandon a formal equality model and replace it with an anti-subordination model that measures equality by virtue of the substantive educational results attained by school districts, not whether they used raceconscious means to attain those results.

\section{SEATTLE AND JEFFERSON COUNTY}

\section{A. Seattle}

The record in the Seattle case shows how difficult it is to get the community to cooperate with attempts to integrate schools at the youngest grades, and to accept efforts that have a mandatory school assignment component. In 1977, Seattle adopted a plan that "divided the district into zones, within which majority-dominated elementary schools were paired with minority-dominated elementary schools to achieve desegregation. Mandatory high school assignments were linked to elementary school assignments, although various voluntary transfer options were available."'10 A state initiative soon attempted to stop this plan, although the United States Supreme Court ultimately declared the initiative unconstitutional. ${ }^{11}$ Seattle

${ }^{10}$ Parents Involved 9th Circ. IV, 426 F.3d at 1168.

11 Washington v. Seattle Sch. Dist. No. 1, 458 U.S. 457, 470 (1982). 
modified its desegregation plan in 1988 to decrease its reliance on mandatory busing, which, under the prior plan, had required the mandatory busing of nonwhite students in disproportionate numbers. ${ }^{12}$ Community dissatisfaction, rather than educational outcomes, seems to have caused these changes. ${ }^{13}$ In 1998, Seattle made further modifications. This time, it limited its diversity efforts to the high schools, and 90 percent of the students in the district were assigned to their first-choice school. "[O]f the approximately 3,000 incoming students entering Seattle high schools in the 2000-01 school year, approximately 300 were assigned to an oversubscribed high school based on the race-based tiebreaker."14

The Seattle School Board decided to make race a factor in assignment to public high schools in 1998 in order to create more equal educational opportunities in the city. The school district acknowledged that despite its best efforts, "it remains a stark reality that disproportionately, the schools located in the northern end of the city continue to be the most popular and prestigious, and competition for assignment to those schools is keen."15 Because of housing patterns segregated on the basis of both race and socioeconomic factors, it also remained true that minority students tended to live in south Seattle and would not be assigned to schools in north Seattle if neighborhood housing patterns exclusively determined school choice. ${ }^{16}$ Hence, the Seattle School Board created what it called a "tiebreaker" mechanism for schools that were not racially balanced, which it defined as schools in which the racial composition deviated by more than 15 percent from the overall population of the students attending Seattle's public schools. ${ }^{17}$ It limited application of the tiebreaker to students entering the ninth grade and did not use it for students in the higher grades. ${ }^{18}$ Although it experimented with using mandatory busing to achieve racial balance, it abandoned busing in light of parental complaints and, instead, moved to a system whereby parents would request their "choice." 19 The racial balancing plan affected who was given his or her first choice from those who chose one of the five most popular schools as their first choice but did not result in

12 See Parents Involved 9th Circ. IV, 426 F.3d at 1168.

13 See Parents Involved in Cmty. Schs. v. Seattle Sch. Dist. No. 1, 137 F. Supp. 2d 1224, 1225 (W.D. Wash. 2001) [hereinafter Parents Involved District].

14 Parents Involved 9th Circ. IV, 426 F.3d at 1170.

15 Parents Involved District, 137 F. Supp.2d at 1225.

16 See id. at 1238-39.

${ }^{17}$ Id. at 1226.

$18 \mathrm{Id}$. at 1239.

${ }^{19}$ Id. at 1225 . 
anyone's being bussed to those schools who had not selected that school as a first choice.

Litigation ensued after the adoption of the 1998 plan. ${ }^{20}$ Two of the lead plaintiffs alleged that they were assigned to Ingraham High School rather than one of the three premier high schools in Seattle. They alleged that school buses were not available to transport them to Ingraham so that they would have had to spend over four hours commuting to high school each day. Because of the unacceptability of that option, the parents chose to send them to private schools that were presumably closer to their homes. ${ }^{21}$ The Washington Supreme Court later noted when it heard the case that the long commute occurred because the students refused to list the names of any local schools on their school choice form. The Court concluded, "[I]t is impossible to determine what their commute would have been had they participated in the selection process." 22 The district court upheld the plan as meeting various constitutional requirements. ${ }^{23}$ Its primary focus was on whether the program used a racial preference as little as possible to attain racial diversity. The court's opinion focused little attention on two factors that I suggest should be important: (1) whether there was evidence that the academic performance of minority students who benefited from this racial "tiebreaker" appeared to improve as a result of their ability to be educated at one of the excellent schools in predominantly white neighborhoods and (2) whether this program was effective given that it did not begin until ninth grade and was only mandatory for one year of school. Given the greater educational resources that the court acknowledged existed at the most popular schools, it is highly likely that students saw an improvement in educational performance upon being admitted to one of those schools. Nonetheless, the opinion contains no discussion of that fact. Although the educational benefits from integration may have been higher if adopted in earlier grades, it appears that Seattle abandoned using race as a factor in the lower grades for political rather than educational reasons.

On appeal, the Ninth Circuit concluded that the plan violated Washington state law, but did not reach the federal constitutional issues. ${ }^{24}$ It did not discuss the effectiveness of the education offered under the plan; it focused entirely on whether the plan could be considered an impermissible race-conscious plan. Several months later, a petition for rehearing was

20 Parents Involved District, 137 F. Supp. 2d at 1224.

${ }^{21}$ Parents Involved in Cmty. Sch. v. Seattle Sch. Dist. No. 1, 285 F.3d 1236, 1241 [hereinafter Parents Involved 9th Circ. I]

22 Parents Involved in Cmty. Schs. v. Seattle Sch. Dist., No. 1, 72 P.3d 151, 156 n.4 (Wash. 2003) [hereinafter Parents Involved Wash. S. Ct.].

23 Parents Involved District, 137 F. Supp. 2d at 1232-39.

24 Parents Involved 9th Circ. I, 285 F.3d at 1253. 
granted by a three-judge panel and the first appellate opinion was vacated. ${ }^{25}$ The Ninth Circuit requested that the Washington Supreme Court agree to hear the novel state initiative legal issues raised by the case, because the prior decision had rested entirely on other state laws. Although the earlier Ninth Circuit injunction was lifted, the Seattle School District chose to suspend using race as a factor in school assignments. ${ }^{26}$

The Washington Supreme Court agreed to hear the case and concluded that the plan did not violate Washington's statutory or constitutional law. ${ }^{27}$ Although the opinion did not note any specific evidence about the academic success of Washington's integration program, it did note:

[T]here is strong empirical evidence that a racially diverse school population provides educational benefits for all students. Most students educated in racially diverse schools demonstrated improved critical thinking skills-the ability to both understand and challenge views which are different from their own. Research has also shown that a diverse educational experience improves race relations, reduces prejudicial attitudes, and achieves a more democratic and inclusive experience for all citizens. ${ }^{28}$

The Court, however, does not discuss whether those generalities have been shown to be true in Seattle.

After the decision of the Washington Supreme Court, the case returned to the Ninth Circuit. ${ }^{29}$ Once again, the Ninth Circuit invalidated the plan. ${ }^{30}$ This time it did so under the Fourteenth Amendment to the United States Constitution. ${ }^{31}$ The Ninth Circuit's opinion made brief mention of the academic achievement of the students at Seattle's various schools, noting that students at the more elite schools had significantly higher standardized test scores than students at the less desirable high schools. ${ }^{32}$ But the opinion contained no discussion of how those test scores might have been influenced by students' transferring from one high school to another. The Ninth Circuit concluded that the Seattle plan was unconstitutional because its use of race

25 Parents Involved in Cmty. Schs. v. Seattle Sch. Dist., No. 1, 294 F.3d 1084, 1084-85 (9th Cir. 2002) [hereinafter Parents Involved 9th Circ. II].

26 Parents Involved in Cmty. Schs. v. Seattle Sch. Dist., No. 1, 377 F.3d 949, 958 (9th Cir. 2004) [hereinafter Parents Involved 9th Circ. III].

27 Parents Involved Wash. S. Ct., 72 P.3d at 166.

28 Id. at 162 (footnotes omitted).

29 Parents Involved 9th Circ. III, 377 F.3d 949.

$30 \mathrm{Id}$. at 988.

31 Id.

32 Id. at 954 n. 1. 
was not sufficiently narrowly tailored. ${ }^{33}$ The use of race was too mechanical, and other race-neutral mechanisms were not sufficiently explored to attain diversity.

This decision was not the end of the story in the Ninth Circuit. The Ninth Circuit voted to hear the case en banc. ${ }^{34}$ More than a year later, the en banc panel affirmed the injunction issued nearly four years earlier in favor of the school district. ${ }^{35}$ The Ninth Circuit en banc opinion summarized the educational and social benefits that can result from increased diversity, such as improved critical thinking skills, socialization and citizenship advantages, and networking advantages. ${ }^{36}$ But the court did not examine any evidence as to whether the specific plan adopted in Seattle succeeded in achieving those benefits in that section of its opinion. The only evidence specific to the benefits attained in Seattle was brief testimony by the principal of one high school, who stated that "students of different races and backgrounds tend to have significant interactions both in class and outside of class. When I came to [the high school], there were racial tensions in the school, reflected in fighting and disciplinary problems. These kind of problems have, to a large extent, disappeared." 37 The dissent notes that the majority only cited the studies that described the benefits that flow from integration and observed that other studies have reached different conclusions. ${ }^{38}$ Like the majority, the dissent does not point to any evidence to suggest which results-positive or negative - are likely to result in the Seattle context.

The primary focus of both the majority and dissent is whether racial diversity could be attained through means that were not overtly racial. All the judges seemed to agree that racial diversity was good, in itself, but they also seemed to agree that race-conscious means to achieve racial diversity are, themselves, a harm to be avoided. Hence, if Seattle could attain racial diversity through entirely race-neutral means such as a lottery or even the use of socioeconomic status, then the result of racial diversity would be permissible. The only reason that Seattle found itself the subject of protracted litigation was that it used an overt racial factor to attain racial diversity.

The presence or absence of race as a factor is the primary focus of the courts' opinions. The lead plaintiffs alleged that their first-choice schools were oversubscribed and that they were assigned to a school far from their home that would require four hours for a roundtrip commute on public

33 Id. at 980.

34 Parents Involved 9th Circ. IV, 426 F.3d at 1172.

35 Id. at 1166.

36 Id. at $1174-75$.

37 Id. at 1182 (quoting Eric Benson, the principal of Nathan Hale High School).

${ }^{38}$ Id. at $1205-07$. 
transportation. Although many students of their race were able to attend those first-choice schools, their odds of being able to attend would have greatly increased if they were nonwhite because, apparently, every nonwhite applicant was admitted to those first-choice schools. The harm they describe is a long commute, which they may have been able to avoid if race had not been a factor in school selection.

The problem with this logic and focus of the various opinions is that the plaintiffs' first-choice high school would still have been oversubscribed under open admissions if race had not been a factor and Seattle had a system of student choice in admissions. Some kind of tiebreaker would still have been necessary, and they could have found themselves not admitted to their first-choice schools and assigned to less convenient options. Would their "harm" have been lessened if they knew they got an inferior school assignment because of the operation of a race-neutral lottery? I would suggest that they have learned to "game" the legal system by describing their harm in racial terms when, in fact, they simply wanted access to the best education offered by the public school system in Seattle. They, of course, had no reason to complain for a decade when the operation of the status quo gave them access to white-dominated neighborhood schools. It was only when they lost access to their white enclave that they thought to complain. When they no longer could get free access to their local white-dominated public school, they left the public system and paid to have access to a presumably white-dominated private school. They were only "harmed" when the rules of the game no longer benefited whites who lived in middle-class neighborhoods.

On the basis of the empirical literature discussed in Part II, I would suggest that to the extent there is a problem with the Seattle plan, it is that it is too narrowly tailored. Afraid to step on the toes of the public and courts, the City of Seattle came up with a plan that would help a small percentage of the minority students in Seattle who happened to win the lottery to attend one of the predominantly white schools. The formal equality framework under which Seattle had to defend its plan made it virtually impossible to develop an effective, broad-ranging plan. The fact that the Supreme Court could strike down even this extremely narrowly tailored plan suggests that no effective plan is likely to pass constitutional muster because, in terms of the empirical literature, an effective plan would have to start in kindergarten, be widespread, and be mandatory. Such a race-conscious plan might achieve integration and high-quality education, but its use of race would not permit it even to attain serious political or judicial consideration.

The quandary faced by the City of Seattle is caused by the illogical state of equal protection jurisprudence, which has been dominated by the principles of formal equality. The law has developed from the statement from 
Brown that "separate can never be equal" 39 to mean that race can virtually never be an overt factor in trying to attain high-quality education for minority children. Racial diversity is only a permissible objective if it can be achieved through awkward, race-neutral means that, at best, attain incomplete diversity and leave the overwhelming majority of minority students still being educated in substandard educational environments.

What if our lens would change and, instead, we would ask what mechanisms are most likely to attain high-quality education for as many minority students as possible, when a school district has a history of substandard education for those students? Then, we might strike down the Seattle plan for not going far enough by still relegating the majority of minority students to a substandard educational environment, especially in the pivotal early grades. Embracing notions of formal equality, the Supreme Court, by contrast, has said that Seattle has gone too far in devising a very modest plan that seeks only to attain racial diversity for less than half of the students attending ninth grade in their school system.

The school system's desire to attain racial diversity in terms that might be acceptable to the public and the courts caused it to select means that were not even consistent with the empirical literature on the educational benefits of diversity. Their diversity plan did not begin until ninth grade, it included only one year of education (because transferring could occur the following year), and it was mandatory only if the deviation from random diversity was more than 15 percent. Because the overall nonwhite population in the school system was 60 percent, a school would not be subject to the plan if its nonwhite population was as high as 74 percent. It did not apply in seven of the ten Seattle public high schools, and the courts do not provide data for those seven schools. Because schools covered by the plan ranged from 40 to 60 percent nonwhite, though, it is clear that each of the other seven schools is more than 60 percent nonwhite. Of the four "popular" schools covered by the plan, in only three did a shift of nonwhites to the school result. Thus, at most, nonwhites at three of the eleven public high schools operated by the City of Seattle benefited from the integration plan and only at the senior high school grades. Did the plan produce any appreciable improvement in the overall education offered to nonwhites in Seattle? There is no way to know because the various decisions contain no useful data about educational outcomes.

Seattle published an extensive report in December 2006 that tracked student performance over time but contained no data on how the setting for education might affect outcome. ${ }^{40}$ Did African-American students who

${ }^{39}$ Brown v. Bd. of Educ., 347 U.S. 483, 495 (1954) (denouncing the "separate but equal" doctrine and finding that separate educational facilities are inherently unequal).

40 See Steven F. Wright, Seattle Public Schools, Data Profile: District SUMMARY (2006), http://www.seattleschools.org/area/siso/disprof/2006/Prfl2006all.pdf. 
attended schools in which their representation was nearly 10 percent more or less than their expected representation in the population benefit from the socalled advantages of integration? The important point is that a severalhundred-page report that was filled with empirical data does not even ask any questions about how racial composition of schools correlates with educational outcomes. The failure to collect data about the results from different learning environments makes it difficult for school officials to structure better learning environments.

\section{B. Kentucky}

The litigation in Jefferson County, Kentucky, provides a less complete record to discuss. The outcome, though, was the same-the Court struck down the explicit use of race to attain integrated schools. As in Seattle, the plan for Jefferson County, Kentucky, developed over many years. ${ }^{41}$ The Kentucky plan, however, is much more comprehensive and complicated. Kentucky's integration efforts began in 1975 as a result of court-ordered desegregation. ${ }^{42}$ In June 2000, the district court dissolved the desegregation decree and ordered the school district to stop using racial quotas at Central High School, and to reevaluate and redesign the admissions procedures in other magnet schools. ${ }^{43}$ In response to that court order and community feedback, the school district ended its use of race in assignments to Central High School and three other magnet high schools. 44 But it decided to continue to use race as a factor in what are called "magnet traditional schools." 45

As did the Seattle plan, the Kentucky plan sought minority school enrollment within 15 percent of their representation in the student population. ${ }^{46}$ For the Jefferson County area, that meant a range between 15 and 50 percent African American. (There were no other minorities well represented in the population so the court simply considered race in black/white terms.) The Kentucky plan sought to attain racial integration at all grades, not merely ninth grade. ${ }^{47}$

${ }^{41}$ McFarland v. Jefferson County Pub. Schs., 330 F. Supp. 2d 834, 841-48 (W.D. Ky. 2004).

42 Id. at 841 .

43 Id.

44 Id.

45 Id. at $841-42$.

$46 \mathrm{Id}$. at 842.

${ }^{47}$ McFarland, 330 F. Supp. 2d at 845. 
The racial guidelines did not apply to kindergarten. ${ }^{48}$ For the rest of elementary school, children were assigned a school within a "cluster." The clusters were defined, in part, on the basis of racial guidelines in order to attain racial balance. Students were able to request their first- and secondchoice schools within the cluster, and nearly all children received one of their two first choices. In middle school and high school, students could attend their neighborhood school or apply for a nontraditional magnet school. Racial guidelines were a factor in admission to some of the magnet and optional programs. ${ }^{49}$

The focus of the litigation was on what were described as "traditional magnet schools." These schools included four elementary, three middle, and two high schools. ${ }^{50}$ The traditional program was also offered within two schools and was open to students on a districtwide basis. The traditional schools emphasized basic skills in a highly-structured environment and parent participation. ${ }^{51}$ Race was used in a more overt way at the traditional schools than at the other schools in the district. Applicants were placed on four lists: black male, black female, white male, and white female. ${ }^{52}$ Applicants were chosen from those lists in a way that guaranteed a racial balance (although race was not a factor in selection into kindergarten). ${ }^{53}$ Because fewer black than white students tended to apply to traditional schools, black applicants had a higher chance of acceptance to traditional schools than white applicants. ${ }^{54}$

As in the Seattle litigation, the focus of attention was on whether the program used race as little as possible. The effectiveness of the plan in achieving high-quality education was, at most, a footnote in the courts' opinions. The district court recited the general observation that "racial integration benefits Black students substantially in terms of academic achievement" but offered no evidence as to whether that generalization held true for that school system. ${ }^{55}$ In one footnote, the district court commented that students reported in a survey that they thought that going to school in an integrated environment would make them more comfortable working within an integrated workplace. ${ }^{56}$ The district court struck down the plan for

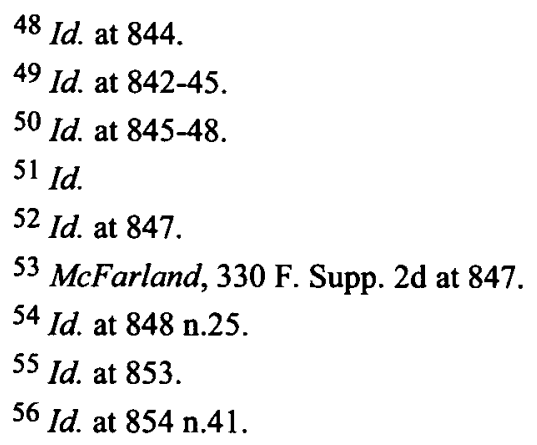


allocating students to the traditional magnet schools because the means used looked too much like a quota. ${ }^{57}$ The court disapproved of the use of separate lists for blacks and whites and concluded that the school district could have attained diversity through less race-conscious means. For students who were not admitted to their first choice because it was oversubscribed, the court concluded that the harm to those students was greater through the use of two separate lists of students rather than a general lottery. No one asked whether the Kentucky plan was successful in improving the academic performance of minority students. The Sixth Circuit affirmed the district court's opinion without further reasoning. ${ }^{58}$

As with the district court, the focus of the Supreme Court's reasoning was on whether the plan was sufficiently "narrowly tailored"--whether it used race as little as possible to achieve integration. The Supreme Court concluded that the Kentucky plan was unconstitutional because its raceconscious measures seemed unnecessary to the attainment of diversity. In Young Elementary, for example, the Court criticized the school district for not being willing to tolerate an enrollment that was 46.8 percent black. Citing Jefferson County's claim that it needed to have its schools constitute "at least 20 percent" minority group representation "to be visible enough to make a difference," the Court noted that 46 percent is far greater than 20 percent and therefore should not be problematic. ${ }^{59}$ But the Court's analysis is overly simplistic and overlooks data that suggest that schools with such high concentrations of African Americans are likely to offer poor educational programs for racial minorities. While it may also be true that racial minorities need a critical mass of 20 percent participation to attain positive results in predominantly white educational environments, it is also true that schools like Young Elementary are also likely to attain poor results for African-American children.

In theory, Chief Justice Roberts is open to considering evidence about how racial diversity provides educational benefits. He says, "This working backward to achieve a particular type of racial balance, rather than working forward from some demonstration of the level of diversity that provides the purported benefits, is a fatal flaw under our existing precedent." 60 But it is hard to know whether he sincerely means that such evidence could be allowed to support race-conscious measures given his adamant language about the inappropriateness of using race as a criterion in school admissions. Although the studies submitted to the Court might have been able to answer

57 Id. at $858,862-64$.

58 McFarland v. Jefferson County Pub. Schs., 416 F.3d 513, 514 (6th Cir. 2005).

59 Parents Involved, 127 S. Ct. at 2756.

${ }^{60} \mathrm{Id}$. at 2757. 
some of those questions, the Roberts opinion makes no attempt to analyze the studies to answer that question. The Court merely asserts that using racespecific means to help "students see fellow students as individuals rather than solely as members of a racial group ... is fundamentally at cross-purposes with that end" without examining any data about students' educational experiences in various educational environments. ${ }^{61}$ An examination of our actual educational experiences, rather than platitudes, might help us shape effective educational strategies.

\section{Observations}

If one steps back and looks at the legal reasoning that has developed in the race context, it makes little sense. School districts are allowed to try to achieve racial integration so long as they do not use race to achieve that goal. In other words, if they are devious and find race-neutral ways to achieve integration, then they are all right. But, if they are explicit about trying to attain integration by using race-specific means, then their programs are unlikely to pass constitutional muster.

But why do we care so much about integration? An important reason that we value integration is a conviction that it helps attain the best possible education for minority children who have historically languished in substandard single-race schools. If the explicit use of race is shown not only to attain integration but to attain high-quality education for minority children, then such use of race should certainly be permissible. Given our history of subordination on the basis of race, it is hard to see how race-conscious, integrated education that attains positive outcomes can be unconstitutional. Ironically, the courts' disfavor of the use of racial categories has hampered the ability of school systems to attain high-quality education for racial minorities. They are forced to use indirect (race-neutral) means or, if they use race at all, to use it in a very limited manner that is unlikely to be effective. Hence, the City of Seattle has been put in the uncomfortable position of defending its use of race in only ninth grade for less than 10 percent of the students, and it abandoned even that modest use of race in the face of litigation. Jefferson County, Kentucky, has sought to defend a broader use of race, but the litigation's fifteen-year history provides little evidence of how the use of race was connected to improved academic performance for minority students.

As the next section will demonstrate, it is very likely that minority students who attend racially integrated schools do perform better academically than their peers who attend single-race schools. That success, however, is likely to depend on the explicit use of race to attain meaningful

61 Id. at 2759. 
integration. Unfortunately, Supreme Court jurisprudence will make it difficult for school districts to attain those kinds of educational benefits.

\section{THE EMPIRICAL DATA}

In this section, I discuss the empirical data cited by the Court in the Seattle litigation to argue that the Court did not examine those data adequately or fairly. Then, I examine empirical data that were available but not cited by the Court that could provide us with more evidence on what kinds of educational programs are likely to be effective. The data suggest that Seattle's modest approach of integrating a few high schools is not likely to be effective and that Kentucky needed to set a higher threshold for what it considered an adequate racial balance to attain strong results. But, of course, from the Court's perspective, such modifications would have made the programs more rather than less unconstitutional.

\section{A. Empirical Data Cited by the Court}

In 1978, Robert Crain and Rita Mahard authored a very thoughtful study in which they examined seventy-three studies that sought to examine the effects of school desegregation on black children. Rather than simply conclude whether desegregation raised the achievement scores of black students, they sought to identify which factors were most closely correlated with positive outcomes for black students. ${ }^{62}$

Their research revealed that several factors had a positive association with academic achievement for black children. First, they found that desegregation was most effective when it occurred at an early age. ${ }^{63}$ They concluded that the "critical point" for desegregation to be effective was grade three or four, a finding that is consistent with other research that has concluded that that age range is a "vulnerable age."64 They suggested that desegregation efforts are similar to geographic migration: "[T]he elementary school years are an important period for establishing social relationships, so that social relationship should not be disrupted during this time." 65 Their research therefore suggests that school districts should do their utmost to create an integrated educational environment during the early years of elementary school.

62 Robert Crain \& Rita Mahard, Desegregation \& Black Achievement: A Review of the Research, 42 LAW \& CONTEMP. PROBS. 17, 17 (1978).
63 Id.
${ }^{64}$ Id. at $36-37$.
$65 \mathrm{Id}$. at 38 . 
Second, they concluded that the curriculum available at the desegregated school has an important effect on educational gains. They note that some researchers have suggested that one is more likely to see gains in math than reading as a result of desegregation, but they account for that difference by observing that it is simply often easier to make major changes in a math curriculum. Because of the role of curriculum in creating educational effects, they note that some segregated schools with strong curriculums have managed to compare favorably with desegregated schools in their community in some subject areas. ${ }^{66}$ In terms of their research, one would expect that modern "magnet" schools that highlight strong curriculums in certain subject areas would particularly benefit from accompanying desegregation effects.

Third, their research resulted in the somewhat surprising conclusion that mandatory desegregation plans are more likely to achieve positive academic results for black children than voluntary plans. They examined each of the mandatory or voluntary desegregation studies very carefully and concluded that only two well-designed studies using voluntary desegregation demonstrated a positive educational outcome for black children. By contrast, they found seven strong studies involving mandatory desegregation that reflected positive educational outcomes for black children. ${ }^{67}$ They carefully considered various hypotheses to explain these counterintuitive results and tried to relate them to previous observations about the challenges inherent in social migration for children. They suggested that black children fare better under mandatory desegregation programs because the desegregated school might be making stronger attempts to adjust in order to accommodate them. Further, black children may be more likely to move to a new school with peers from their neighborhood. ${ }^{68}$ More recent studies have concluded that "there are stronger achievement gains when desegregation is voluntary." 69

The Crain and Mahard study was consistent with the findings from an article authored nearly two decades later by Maureen Hallinan. ${ }^{70}$ As Crain and Mahard had, Hallinan carefully reviewed the empirical evidence on student performance in various learning environments and examined what factors were most likely to be associated with strong academic performance for minority students in majority-white schools. She found that " $[t]$ he earlier a black student is placed in a majority white school or classroom, the higher

66 Id. at $38-39$.

67 Id. at 40.

68 Crain \& Mahard, supra note 62 , at 45-47.

69 Brief of 553 Social Scientists as Amici Curiae Supporting Respondents at App. 14, Parents Involved, 127 S. Ct. 2738 (2007) (Nos. 05-908 and 05-915).

${ }^{70}$ Maureen T. Hallinan, Diversity Effects on Student Outcomes: Social Science Evidence, 59 OHIо ST. L. J. 733 (1998). 
the student's academic achievement."71 She also found that "cooperative learning techniques" that fostered friendships between minority and white children were associated with positive educational outcomes for minority children. ${ }^{72}$ From these various findings, she concluded that "peer influence, role modeling, instructional quality, and educational expectations are factors that transmit the effects of desegregation to student achievement." 73 Then, stepping back to consider broad research on how students learn, she concludes: " $[1] \mathrm{t}$ is not desegregation per se that improves achievement, but rather the learning advantages some desegregated schools provide." 74 In other words, desegregation only produces positive educational outcomes for minority children if accompanied by some of the other factors discussed by Hallinan (as well as Crain and Mahard).

These studies could have been used by the Court to assess whether the Seattle and Louisville desegregation efforts were likely to be successful. Chief Justice Roberts's opinion discusses none of these studies; they only receive mention from other members of the Court. Justice Thomas cites the Crain and Mahard study for the proposition that some scholars "have concluded that black students receive genuine educational benefits" from what he calls "racial balancing." 75 Crain and Mahard, however, disavow an interest in being put in the "positive" or "negative" camp for the effects of desegregation. ${ }^{76}$ The purpose of their study was to identify factors that lead to successful programs rather than proclaim that all desegregation efforts are positive or negative. ${ }^{77}$

As for the Hallinan article, Justice Thomas dismisses its usefulness quickly by noting Hallinan's ending observation about the importance of the learning opportunities available at the desegregated school. ${ }^{78}$ But he takes that observation completely out of context, not acknowledging the careful previous discussion about what factors are likely to lead to positive educational outcomes. The fact that Hallinan does not simplistically attribute desegregation to a positive educational outcome does not mean that she considers desegregation to be an irrelevant factor. As are Crain and Mahard, she is trying to help shape social policy by giving school districts insight into how to achieve effective desegregation.

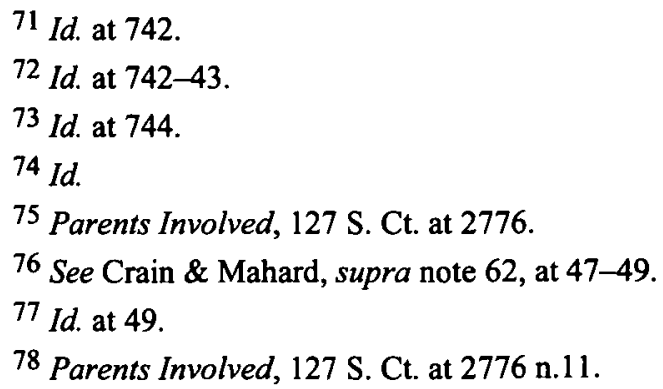


Justice Thomas's opinion gives significant weight to studies that tried to determine whether desegregation, as a whole, has led to positive educational outcomes for minority children. One of the most thorough literature reviews provided to the Court on this topic was an amicus brief written on behalf of the social scientists David J. Armor, Abigail Thernstrom, and Stephan Thernstrom. ${ }^{79}$ While acknowledging that the Crain and Mahard study did find positive results for children who benefited from desegregation in early grades, they concluded that there is "no clear and consistent evidence" that desegregation produces positive educational outcomes for minority children. ${ }^{80}$ Not surprisingly, other social scientists submitted amicus briefs disputing Armor and colleagues' overall conclusion, suggesting that their argument rested on "incomplete analyses of the literature, critiques of wellestablished scientific methodologies, and reliance on studies that are outdated or inconsistent with more recent research." 81 This amicus brief, like the Armor et al. brief, does not offer good guidance on what kind of educational program is likely to generate positive results. The fact that desegregation may have produced a range of results is not a very surprising (or helpful) finding. More important is which factors tend to lead to successful desegregation attempts.

Justice Kennedy's opinion in Seattle is often seen as the pivotal opinion because it provides the important fifth vote to strike down the school districts' race-conscious desegregation efforts. Because his opinion is less sweeping than that of Chief Justice Roberts in dismissing the use of race in school assignments, school officials are likely to read his opinion closely for hints as to how they might fashion a constitutionally permissible raceconscious plan. The Kennedy opinion, however, does not reflect consideration of any of the empirical work on effective desegregation programs. His sole concern seems to be how "narrowly tailored" is the use of race. ${ }^{82}$ He suggests ways that school districts might attain desegregation and use less race-conscious mechanisms such as "strategic site selection of new schools; drawing attendance zones with general recognition of neighborhood demographics; allocating resources for special programs; recruiting students and faculty in a targeted fashion; and tracking enrollments, performance, and

${ }^{79}$ Brief of David. J. Armor, Abigail Thernstrom \& Stehpan Thernstrom as Amici Curiae in Support of Petitioners, Parents Involved, 127 S. Ct. 2738 (Nos. 05-908 and 05915) [hereinafter Armor Brief.

80 Id. at 29.

81 Brief of the American Educational Research Association as Amicus Curiae in Support of Respondents at 2 n.3., Parents Involved, 127 S.Ct. 2738 (Nos. 05-908 and 05915).

82 Parents Involved, 127 S. Ct. at 2744. 
other statistics by race." 83 Kennedy is correct that those mechanisms might be more "narrowly tailored," but the more important question should be: Are they likely to produce better educational results for African-American children? Justice Kennedy's opinion notes that the famous axiom that "our Constitution is color-blind" cannot be a universal constitutional principle if we are to overcome a legacy of race discrimination in the United States. ${ }^{84}$ Nonetheless, he uses the "color-blind" criterion as the primary yardstick in determining the constitutionality of a school's desegregation efforts.

Justice Thomas and Justice Breyer extensively cite empirical literature in their opinions in the Parents Involved case but primarily use those citations to determine whether desegregation has led overall to positive educational outcomes for minority children. Neither opinion spends much, if any, time isolating what factors might lead to positive educational outcomes. Although Justice Kennedy seeks to offer a middle ground position that leaves open the possibility of the narrow use of race-conscious mechanisms to attain integration, he does not rely on empirical research to identify acceptable race-conscious mechanisms.

\section{B. Empirical Literature Not in the Parents Involved Litigation}

One problem for the Supreme Court in these kinds of cases is that it is being presented with empirical evidence for strategic purposes-in support of arguments made by proponents of a particular position. The justices may not have the inclination or the skills to read these studies closely or to look beyond the studies called to their attention by litigants.

Undoubtedly, there are many studies that the Court could have examined that were not cited by litigants, possibly because they did not lend themselves to quick "sound bites" that could be cited in support of one proposition or another. In this section, I would like to examine some data not discussed by the Court that might lend insight into how to develop effective integration programs that are likely to lead to positive educational outcomes for minority children. ${ }^{85}$ Data collected from the Texas public schools, which are not cited by the Court in the Parents Involved litigation, support the argument that minority students are likely to improve their academic performance if they attend integrated schools rather than predominantly black schools. As do the

$83 \mathrm{Id}$. at 2745.

${ }^{84}$ Id. at 2791-92.

${ }^{85}$ I have examined these data closely because they were the most comprehensive data that I was able to locate while writing this Article. I am not an expert in this area and would welcome others to examine other data that might be available. My discussion simply reflects the kinds of questions we might ask of such data, and what conclusions might be plausible. 
data discussed earlier, their data also support the argument that integration must start in the early grades and must create genuine, rather than token, integration to be effective.

The Texas data are remarkable and provide many opportunities for researchers to consider many important policy issues. The Texas Schools Microdata Panel (TSMP) collected data for more than two million students over at least an eight-year period. ${ }^{86}$ The data contain more than twenty-six years/grades of standardized test data for three different standardized tests. ${ }^{87}$ The students are identified by many factors and the data include millions of records. ${ }^{88}$

The first assessment of these data that is relevant to the present study is the relationship between where African-American children receive their education (suburbs or inner city) and educational levels. John F. Kain and Daniel M. O'Brien studied that question for a working paper series published by the Cecil and Ida Green Carter Center for the Study of Science and Society. ${ }^{89}$ After controlling for many factors, including the prior year's reading or math score, they concluded that African-American students who would move from an inner-city school in Texas to a suburban school would be likely to see a "substantial improvement" in educational attainment as measured by standardized tests. ${ }^{90}$ In this 1998 study, they did not discuss the differences between suburban and inner-city school districts as being one of the differences in racial composition. They simply considered the suburban schools to be "better" schools and concluded that African Americans would be likely to show substantial improvement in standardized test scores if they were able to attend these suburban schools. ${ }^{91}$

Two years later, they offered a refined version of the prior paper. ${ }^{92}$ In this paper, they provided the percentage of black enrollment in inner-city and

86 John F. Kain \& Daniel M. O'Brien, Black Suburbanization in Texas Metropolitan Areas and its Impact on Student Achievement 2 (Educ. Res. Serv. Ctr., ERIC No. ED478407, 2000), available at http://eric.ed.gov./ERICdocs2sq1/ content_storage_01/ 00000196/80/1b/0f.pdf.

87 Id. at 2-3 n. 1 .

88 John F. Kain \& Daniel M. O'Brien, How Much Has Moving to the Suburbs Increased African American Educational Opportunities? 2-3 n.l (Jan. 5, 1998) (paper prepared for the meetings of the American Economic Association, Chicago, Illinois) (unpublished article, on file with the Cecil and Ida Green Center for the Study of Science and Society working paper series), available at www.utdallas.edu/research/tsp/pdfpapers/aeapapj229f.pdf.

${ }^{89}$ Kain \& O'Brien, supra note 86.

90 Id. at 35 .

$91 \mathrm{Id}$.

92 See Kain \& O’Brien, supra note 88. 
suburban school districts. Not surprisingly, the percentage of all students who were African American was higher in the inner city than suburban school districts. ${ }^{93}$ They described "inner city black exposure to Anglos" as about 11 percent during the years of the study and "suburban black exposure to Anglos" as ranging from 42 to 47 percent during the years of the study. 94 (Anglos are not a majority in the suburban districts because of the presence of Asians and Hispanics.) This paper made two other observations not found in the prior paper. First, they investigated whether access to suburban schools has as big an influence on Asian, Hispanic, and Anglo students as it does on African-American students. While they found that attending a suburban school had a positive impact on those groups, they found that the effect was smaller than for African-American students. ${ }^{95}$ Further, they tried to quantify what would be the result if more African-American students attended suburban schools. They concluded that "attending a school of average suburban quality would eliminate nearly 58 percent of the black-white achievement gap for fifth graders, 27 percent of the black-white achievement gap for sixth graders and nearly 38 percent of the black-white achievement gap for seventh graders." 96

Finally, in 2002, John Kain joined with Eric Hanushek and Steven Rivkin to ask how school racial composition affects student academic achievement. ${ }^{97}$ Using the same data set, they were able to control for school quality, differences in student abilities, and family background. After controlling for these factors, they concluded that the academic performance of African Americans was better in integrated settings than in settings with high concentrations of African-American students. ${ }^{98}$ This effect was strongest for those in the upper half of the ability distribution; in fact, there was only statistical significance for those in the top two quartiles of

\footnotetext{
${ }^{93} I d$. at 31 , tbl. 3 .

94 Id. at 10 .

95 Id. at 25.

96 Id. at 23-24.
}

97 Eric A. Hanushek, John F. Kain \& Steven G. Rivkin, New Evidence About Brown v. Board of Education: The Complex Effects of School Racial Composition on Achievement 1 (Nat'l Bureau of Econ. Research, Working Paper No. 8741, 2002), available at http://www.nber.org/papers/w8741. They updated their data further in 2008, reaching the same conclusions. Eric A. Hanushek, John F. Kain \& Steven G. Rivkin, New Evidence About Brown v. Board of Education: The Complex Effects of School Racial Composition on Achievement (rev. Jan. 2008), available at http://edpro.stanford.edu/Hanushek/files_det.asp?FileId=142. For a critique of the Hanushek data, see David J. Armor, Lessons Learned from School Desegregation in Generational Change: Closing the Test Score GaP 115 (Paul E. Peterson ed., 2006).

${ }^{98}$ Hanushek et al., supra note 97 , at 28. 
achievement. ${ }^{99}$ The racial composition of the classroom was not found to have a significant impact on the academic performance of whites or Hispanics, strongly suggesting that the results were not a simple reflection of unmeasured school quality.

Their research suggests that it is very important to begin integration, especially for high-achieving African Americans, in the early grades because the effects of integration are cumulative. ${ }^{100}$ Moreover, 10 percent changes in racial composition can have a statistically significant effect on the achievement of African-American children. They reported: "The magnitude of the proportion black coefficient for blacks of -0.25 suggests that a 10 percentage point reduction in percentage black would raise annual achievement growth by 0.025 standard deviations. These estimated effects apply to the growth of annual achievement and thus accumulate over grades." 101 This 10 percent figure is important because, as we have seen in Seattle and Louisville, school districts have been permitting a large degree of racial imbalance before requiring racial desegregation efforts. Yet, this empirical literature suggests that more than a 10 percent racial imbalance should not be permitted, especially for high-achieving African-American students.

While no empirical research is perfect, other researchers have described the Texas study as effectively controlling "for a variety of potential confounding factors, including student-specific rates of change in achievement test scores and hard-to-measure factors that vary at the level of the school-by-grade or even attendance zone-by-year."102 Reviewing the available studies, these researchers have also concluded, "A complete elimination in district efforts to integrate public schools could raise test score gaps significantly in some cases." 103 That conclusion was offered before the

${ }^{99}$ Id. at 25.

100 Willis Hawley, in a nonempirical book chapter, agrees with the conclusion that what he calls "diverse learning opportunit[ies]" are most beneficial if they begin in early grades. See Willis D. Hawley, Designing Schools That Use Student Diversity to Enhance Learning of All Students, in Lessons IN INTEGRATION: REALIZING THE PROMISE OF RACIAL DIVERSITY IN AMERICAN SCHOOLS 32 (Ericka Frankeberg \& Gary Orfield eds., 2007).

${ }^{101}$ Hanushek et al., supra note 97, at 23.

102 Jacob Vigdor \& Jens Ludwig, Segregation and the Black-White Test Score Gap 20-21 Nat'l Bureau of Econ. Research, Working Paper No. 12988, 2007, available at http://www.nber.org/papers/w12988.

103 Id. at 24. 
Seattle decision made it more difficult for school districts to engage in desegregation efforts. ${ }^{104}$

The most significant critique of the Texas data has been offered by David Armor in an amicus brief he submitted in the Seattle case and in an article he authored primarily to dispute the results from the Texas study. ${ }^{105}$ The gist of his critique is that the Texas data cannot be accurate because it is not consistent with other studies of the effectiveness of school desegregation plans. In the amicus brief, he suggests that the Hanushek study must be wrong because it "is not consistent with the case studies above and may reflect a problem with the model or the data." 106 Yet, he never identifies with any specificity what those problems might be. Similarly, in his 2006 article which seeks to critique the Hanushek study, he concludes that Hanushek must be wrong because other researchers in Texas, using other methodological strategies, have reached different findings. ${ }^{107}$ The Hanushek study, however, examined test results over time whereas the other Texas studies were cross-sectional. ${ }^{108}$ The fact that a longitudinal study reveals different results than a cross-sectional study does not mean that the data from the longitudinal study are inaccurate. Although Armor criticizes the lower courts in the Seattle litigation for reviewing a "very limited and biased record," 109 his review of the record has a similar problem because he dismisses one of the largest data sets ever constructed on student educational performance to reach his conclusions about the ineffectiveness of desegregation efforts. ${ }^{110}$

104 Professor St. John drew a similar conclusion in some of her earlier work. She concluded: "[E]arly school desegregation as well as classroom percentage white contributed significantly and positively to sense of environmental control, even with SES held constant." NANCY H. ST. JOHN, SCHOOL DESEGREGATION: OUTCOMES FOR CHILDREN 53 (1975) (referencing McPartland's 1968 reanalysis of the Coleman report data). Similarly, Professor Mickelson concluded that racial isolation at an early age had an adverse effect on African-Americans, suggesting that desegregation efforts should try to reach the early grades. See Roslyn Arlin Mickelson, Subverting Swann: First- and Second-Generation Segregation in the Charlotte-Mecklenburg Schools, 38 AM. EDUC. RES. J. 215, 229-31 (2001).

105 Armor Brief, Parents Involved, 127 S. Ct. 2738 (2007) (Nos. 05-0908 and 05915); Armor, supra note 97.

106 Armor Brief at 21 n.41 Parents Involved, 127 S. Ct. 2738 (2007) (Nos. 05-0908 and 05-915).

107 Armor, supra note 97, at 136.

108 Id. at 97.

109 Armor Brief at 11, Parents Involved, 127 S. Ct. 2738 (2007) (Nos. 05-0908 and 05-915).

110 In other work, Armor also goes to great lengths to dismiss the value of any work that suggests that desegregation leads to positive educational outcomes for African- 
While the Texas data offer some of the best support for the positive value of desegregation efforts, other studies also support such conclusions. Jomills Braddock and Tamela Eitle did a literature review of both the short term and long term effects of desegregation on various measures including academic achievement. ${ }^{111}$ They concluded that the evidence supports both short term and long term gains - the desegregation of schools allows African Americans to attain higher academic achievement in the short term which leads to them surmounting structural barriers to employment in the long term. ${ }^{112}$ Similarly, Jonathan Guryan examined the effect that school desegregation has on high school drop-out rates. ${ }^{113}$ Using census data, and controlling for various factors, he concluded that desegregation caused a two to three percent dropout rate for black students, but had little or no effect on the dropout rate for white students. ${ }^{114}$ Districts that were more effectively integrated showed greater decline in the dropout rate. ${ }^{115}$ Unlike the studies, though, that emphasized the importance of desegregation efforts starting early, this study found that there was no evidence that length of exposure to desegregation had a "compounding effect on dropout rates."116 Dropping out of school, however, is not the same as academic performance, so this is not a different result of much significance.

The study that best supports the Hanushek study from the Texas data is one conducted by Shelly Brown-Jeffy. ${ }^{117}$ She examined test data from the

Americans. Although he notes that the reading scores of African-Americans were closer to those of whites when the school was between 61 and 99 percent white, he rejects this result as not "reliable." David J. Armor \& Christine H. Rossell, Desegregation and Resegregation in the Public Schools in BEYOND THE COLOR LINE: NEW PERSPECTIVES ON RACE AND ETHNICITY IN AMERICA 219, 243 (Abigail Thernstrom \& Stephan Thernstrom eds., 2002), available at http://media.hoover.org/documents/0817998721_219.pdf. Similarly, Armor and Rossell note that math scores improve in schools that are over 40 percent white but they do not credit those results as being related to desegregation because the scores of both whites and African-Americans improved. Id. at 250-51.

111 Jomills Henry Braddock II \& Tamela McNulty Eitle, The Effects of School Desegregation, in HANDBOOK OF RESEARCH ON MULTICULTURAL EDUCATION 828-843 (James A. Banks \& Cherry A. McGee Banks eds., 2d ed. 2004).

112 Id. at 829.

113 Jonathan Guryan, Desegregation and Black Dropout Rates, 94 AM. ECON. REV. 919,919 (2004).

114 Id.

$115 \mathrm{Id}$.

116 Id. at 935 .

117 Shelly Brown-Jeffy, The Race Gap in High School Reading Achievement: Why School Racial Composition Still Matters, 13 RACE, GENDER \& Class 268 (2006). See also Shelly Brown-Jeffy, School Effects: Examining the Race Gap in Mathematics Achievement, J. AFR. AM. STUD., (2008), http://www.springerlink.com/ 
early 1990s to determine the influence of school racial composition on the achievement gap between Black, Hispanic, Native American, and White students. ${ }^{118}$ The dependent variable for the study was twelfth grade reading achievement. ${ }^{119}$ For the purpose of this study, she grouped Black, Hispanic and Native American into one category (but did not include Asians in her minority category). Her results support the "critical mass" argument for effective school desegregation - that the best academic results are achieved when the school is $10-24 \%$ minority. 120 " $[\mathrm{S}]$ chools with less than $10 \%$ Black, Hispanic and/or Native American student populations are not the schools that exhibit the largest mean reading achievement scores, even when controlling for socioeconomic status." 121 This research therefore supports the argument that desegregation is more likely to achieve positive educational results for minority children when it is more than token integration.

At the conclusion of his Article, Armor notes that there is inconsistent evidence about what types of desegregation programs are effective. ${ }^{122} \mathrm{He}$ suggests that it would be a positive outcome if research could clarify why "black concentration appears to have adverse effects on black achievement in some states or school districts but not others." 123 This Article has suggested two factors that might cause desegregation efforts to be effective-early exposure to integration and more than token integration. Sufficient evidence supports those strategies that school districts should be given the leeway to try to improve minority educational performance through such mechanisms.

\section{CONCLUSION}

The Supreme Court's decision in the Parents Involved litigation presents school districts with few effective options. Justice Kennedy is considered to be the "swing vote" in this kind of litigation, and he did not embrace the most extreme formal equality language found in Chief Justice Roberts's opinion. But there is no reason to believe that Justice Kennedy would have preferred Seattle or Kentucky to engage in more use of race to attain substantive equality. Playing into the formal equality model, he embraced the notion that race should be used as little as possible in school assignments. As

content $/ 94700718 \mathrm{~m} 3 \mathrm{k} 15684 /$ fulltext.pdf (finding that schools with $30-49 \%$ Black or Hispanic students exhibit more equivalent math test scores between White and Hispanic students than schools with more than $50 \%$ Black or Hispanic students).

$118 \mathrm{Id}$. at 273.

119 Id.

$120 \mathrm{Id}$. at 285.

121 Id.

122 Armor, supra note 97, at 140.

123 Id. 
this Article has argued, that kind of minimalist approach might appease the parents of white children but is unlikely to attain substantive equality for African-American children.

It would appear that the primary hope for progress in the racial area is for a transformation in the membership of the Supreme Court. The only good news is that the Texas school data suggest that meaningful integration can help attain dramatic increases in educational attainment for AfricanAmerican children. ${ }^{124}$ The bad news is that neighborhood housing patterns are unlikely to attain such integration "naturally," and the Supreme Court has precluded the kind of race-conscious policies that can attain those results deliberately.

While formal equality notions may have assisted the Court in rejecting segregation in Brown v. Board of Education, it has outlived its usefulness as a vehicle to attain substantive equality. An anti-subordination perspective that does not reflexively dismiss race-conscious tools is needed to attain genuine equality in our society. Some school districts are willing to implement such tools, but they can only do so in a more receptive legal environment.

124 This is not to suggest that more integration necessarily leads to positive results. Any change in educational policy must be constructed carefully to be effective. Willis Hawley has done an excellent job describing what types of diverse learning opportunities are likely to lead to positive outcomes. See Hawley, supra note 100 . He has found that certain racial balances lead to better outcomes, that it is best to begin integration in the early grades for it to be effective, that it is useful to engage in collaborative cross-racial projects which value rather than stereotype differences, and that various school policies and environments can help create more beneficial diverse learning environments. 
